\title{
Climate Change and State Interest
}

\section{Anatol Lieven}

\begin{abstract}
Anatol Lieven is a British author, Orwell Prize-winning journalist, and policy analyst, currently serving as a professor at Georgetown University, visiting professor at King's College London, and fellow at the New America Foundation.

This is an edited version of the paper originally written for the Valdai Discussion Club (https://valdaiclub.com/a/highlights/climate-change-and-state-interest/)

DOI: $10.31278 / 1810-6374-2021-19-1-200-204$
\end{abstract}

The future of negotiation and action on limiting climate change is likely to be characterized by Realist considerations of state interest and power, but with a new understanding of state interest shaped by moral pressure from international communities. Hopefully, this will lead to a new form of enlightened self-interest in time to save us all from disaster, Valdai Club expert Anatol Lieven writes.

The Valdai report on climate policy in a global risk society highlights a tragic paradox that has also been emphasized by the experience of the coronavirus pandemic, with humanity facing challenges in a world dominated by strong and independent sovereign states. Clearly these are issues that should lead to the creation of new international institutions and international cooperation in response to the current predicaments.

Whether this will really happen is extremely doubtful, however. At the time of writing, the response to the pandemic in some states has been overwhelming; to some extent, it appears to be necessary, 
since only states could impose lockdowns, close borders and mobilize national health services.

Worse still, the pandemic, which would have been expected to bring the great powers together, has actually increased hostility among them. This would probably not have happened if it had originated in some neutral country; but the Trump administration's vicious attempt to divert attention from its own incompetent response by blaming China, and the aggressive (and often mendacious) Chinese response have badly damaged the World Health Organization, one institution that has always been touted as the greatest United Nations success story.

The point is that the WHO functioned for decades in such an effective and consensual way because no major power had national interest either in maintaining infectious killer diseases in the world or in gaining control of the WHO.

As soon as diseases and disease control became objects of national prestige and competition, the WHO became a field of struggle.

As the report warns, the pandemic may well increase belief in the importance of state power and state ability to regulate the lives of citizens. The contrast between the success of East Asian states in curbing the pandemic and the abject failure of several Western ones certainly seems to provide a stark lesson in this regard.

This is not a simple contrast between democratic and authoritarian systems: not just authoritarian China, but also democratic Japan, South Korea, and Taiwan have performed magnificently, while several authoritarian and semi-authoritarian states around the world have performed poorly. Rather, it is a question, on the one hand, of state efficiency and willingness to intervene and regulate, and on the other hand, of disciplined populations that are prepared both to accept this kind of state regulation and trust expert advice.

The experience of the U.S., Britain, Italy, and Spain in the face of the 
pandemic does not set a good precedent for their future behavior if faced with state demands for sacrifice in the struggle to limit climate change. Indeed, the rejection of expert advice and state regulation by many Americans who refused to recognize climate change was replicated precisely by the same sections of the U.S. population in denying the pandemic and rejecting measures to control it. However, in much of Europe, Canada, and Australia people have accepted a degree of restriction on their personal behavior that would have been unthinkable a year ago, and this could provide an important precedent for future willingness to accept restrictions on consumption and movement in an effort to limit carbon emissions.

The report draws an inspiring picture of the impact of climate diplomacy on the part of international activists like Greta Thunberg and international movements like Greenpeace. The direct impact has, however, been limited mostly to Western democracies. Thunberg first came to public attention by picketing the Swedish parliament building. Picketing the Chinese parliament, even if it were allowed, would hardly have had the same effect, if only because it does not really exist. Yet China is now the world's biggest greenhouse gas emitter by far, and its share will grow further in the years to come.

The real problem about climate diplomacy so far is not that it has been carried out by states-in the end, who else could have negotiated international agreements leading to state action? Statements by activists like Thunberg that governments cannot take part in saving the world from climate change are inherently absurd, and the activists do not really believe it themselves when they stop to think. Thunberg picketed the Swedish parliament in order to help persuade Swedish parliamentarians to pressure the Swedish government.

The weapons of international activism are public information, moral pressure on political elites, or to put it more bluntly, shame; and that is essentially also the role of international bodies like the UN's Intergovernmental Panel on Climate Change (IPCC). No international institution or law, however, has the power to compel 
an important state to act or punish it (other than morally) for not acting. This, alas, has been demonstrated many times in the history of the UN over the past seventy-five years.

Analogies between the potential power of international climate regulatory bodies and the power of international sports bodies are, unfortunately, largely incorrect. Sports bodies have punitive power because they can deny access to a small number of extremely prestigious and valuable sporting events; and the U.S. and Russia cannot shoot their way into the Olympics or the World Cup. No international body can deny China access to the world economy, or compel wealthy nations to hand over large sums in climate aid to poorer ones. For such a thing to happen humanity would have to be already suffering from a catastrophic climate crisis.

My sense is that the most important developments in climate diplomacy in the near future will be along different lines: not global but multilateral and often bilateral. And this is not a bad thing. The attempt to reach global agreements on reducing emissions has in many ways been a disastrous distraction, allowing blocking action by individual spoilers which are responsible for only tiny proportions of emissions, like Brazil which last year was only responsible for about one percent of emissions, but which, as the report mentioned, played the leading role in frustrating the Madrid negotiations; or the endless blocking role of poorer developing countries with their morally justified but practically hopeless demands for massive financial compensation from the rich.

The truth is that more than two-thirds of greenhouse gas emissions are accounted for by only six countries (treating the EU as one country); and more than two-fifths are accounted for by only two-China and the U.S.. In other words, an effective agreement between just these two would have a far stronger effect than if all the rest of the world agreed. The key question, therefore, is whether the Chinese and American governing elites can become convinced that the long-term risk of climate change to their states outweighs the short-term risk of economic loss and political unpopularity. 
Negotiations between the U.S. (to a lesser extent the EU and India) and China are likely to be characterized by competition, coercion and cooperation, in that order. The government team of President Biden has already made clear that it will present action on alternative energy to the American people as an essential feature of economic, technological and geopolitical competition with China, which is fair enough, since the Chinese government has long made it clear that it considers its own development of alternative energy technology through this geopolitical lens.

Some of its members have also stated that they intend to link new tariffs on Chinese goods to Chinese action or inaction in reducing emissions; if only because they see that this is the only way of making U.S. climate action acceptable to many Americans. Incidentally, by imposing higher prices for consumer goods on the American public, this also introduces (by opening a sort of geopolitical back door to a new Cold War) the principle that Western consumers should pay for the reduction of emissions in producing countries by limiting their own consumption. The EU is very likely to follow suit, and combine this with new tariffs against Indian goods (something that the Biden administration will find much more difficult to impose given their desire for closer partnership with India). Such sanctions will not compel the Chinese to adopt radically new policies, but they may push them into moving faster with policies that they have already adopted.

The future of negotiation and action on limiting climate change seems likely to be characterized by Realist considerations of state interest and power, but with a new understanding of state interest (in the West, but also to a lesser extent elsewhere) shaped by international communities of moral pressure. Hopefully, this will lead to a new form of enlightened self-interest in time to save us all from disaster. 